\title{
Forecasting of flash floods by Algorithm of Storm Prediction
}

\author{
David Šurr ${ }^{1, *}$, Katerina Víchová ${ }^{2}$ \\ ${ }^{1}$ Tomas Bata University in Zlin, Faculty of Applied Informatics, Nad Stráněmi 4511, Zlin, Czech Republic \\ ${ }^{2}$ Tomas Bata University in Zlin, Faculty of Applied Informatics, Nad Stráněmi 4511, Zlin, Czech Republic
}

\begin{abstract}
This article focuses on the forecasting of flash floods using the Algorithm of Storm Prediction as a new tool to predict convective precipitation, severe phenomena and the risk of flash floods. The first part of the article contains information on methods for predicting dangerous severe phenomena. This algorithm uses mainly data from numerical weather prediction models (NWP models), database of historic weather events and relief characteristics describing the influence of orography on the initiation of atmospheric convection. The result section includes verification of predicted algorithm outputs, selected NWP models and warnings of CHMI and ESTOFEX on three events related to the floods that hit the Zlín Region between years of 2015 - 2017. The main result is a report with prediction outputs of the algorithm visualized in maps for the territory of municipalities with extended competence and their regions. The outputs of the algorithm will be used primarily to increase the effectiveness of preventive measures against flash floods not only by the Fire Rescue Service of Czech Republic but also by the flood and crisis management authorities.
\end{abstract}

\section{Introduction}

Natural disasters are one of the most significant threats to contemporary society, particularly disasters caused by the weather in the Czech Republic and the world. These are mainly floods, storms, and gales. Floods represent one of the most significant direct hazards for the Czech Republic, where there are significant losses in life and economic losses. Floods caused by steady rain significantly affected the Czech Republic in years of 1997, 2002 and 2006. Flood damage amounted to nearly 150 billion. Moreover, dozens of people were killed as a result of heavy rainfall. Floods caused by torrential rainfall (called "Flash floods") have started to occur regularly in the Czech Republic since 2007. Nevertheless, this type of floods has become a current issue of crisis management. At the same time a threat to our entire society due to their high frequency of intensity and short duration of extreme weather phenomena, especially torrential rainfall, which are one of the leading causes of the flash floods $[1,2,3]$.

Extreme weather phenomena associated with strong severe storms are one of the impacts of global climate change with a natural uneven occurrence [5]. Typical consequences of global climate change are the global increase of surface temperature [6] and atmospheric humidity caused by the melting of glaciers, frozen land and sea ice [7], which contributes to growing the frequency of these extreme weather events and also flash floods.

The possibilities of flash floods prediction are still insufficient due to a large number of parameters that affect the formation of flash floods. The reason for the low success rate of predicting intense torrential rainfall and other dangerous phenomena is their local occurrence in a tiny area of several $\mathrm{km}^{2}$ with a short duration (approximately ten of minutes). Current forecasting systems such as numerical weather prediction models (NWP models), nowcasting systems and expert meteorological systems allow predicting the occurrence of torrential rainfall with relatively low success and short lead times. The prediction of intense convective precipitation by NWP models has been investigated in many studies $[8,9,10]$. The fundamental problem of NWP models lies in the lack of horizontal resolution, the amount of input data, including the absence of the effect of orography on the initiation of convection. Nowcasting systems work with data from radar rainfall measurements to calculate the motion field of precipitation using extrapolation methods [11, 12, 13] with a very short lead time (approximately 60 minutes). These systems do not predict variability of rainfall in time including orographic influences. Expert meteorological systems combine previous systems, including conceptual and statistical models of orography, the use of which is documented in some papers $[14,15$, $16]$.

Limitations of expert systems are based on the disadvantages of applied methods. None of these forecasting tools provide relevant prediction information with higher prediction accuracy. For these reasons, the Algorithm of Storm Prediction was developed to solve these problems. The goal of the algorithm is to provide a more accurate predictive information on convective

* Corresponding author: $\underline{\text { saur@utb.cz }}$ 
precipitation and dangerous severe phenomena for the early warning of flash floods with the possibility of deploying preventive flood control measures.

\section{Methods}

The prediction of intense convective precipitation, which is one of the leading causes of the flash floods, is solved through these systems and algorithms with forecast lead time:

1. System Integrated Warning Service of CHMI with forecast lead time 24 hours.

2. The algorithm of Storm Prediction with lead time 624 hours.

System Integrated Warning Service of CHMI provides prediction warning information on dangerous phenomena related to severe storms for the territory of the regions and districts, shown below in Table 1:

Table 1. Classification of dangerous phenomena [17]

\begin{tabular}{|c|c|c|}
\hline Colour & $\begin{array}{c}\text { The degree of } \\
\text { storm } \\
\text { intensity }\end{array}$ & $\begin{array}{c}\text { Rainfall intensity, } \\
\text { dangerous phenomena }\end{array}$ \\
\hline Weak storms & $\begin{array}{c}\text { below } 29 \mathrm{~mm} / \mathrm{hr} ., \text { heavy } \\
\text { rainfall }\end{array}$ \\
\hline Strong storms & $\begin{array}{c}30-49 \mathrm{~mm} / \mathrm{hr} . \text {, heavy } \\
\text { rainfall, hail and strong } \\
\text { wind gust }\end{array}$ \\
\hline & $\begin{array}{c}\text { Very strong } \\
\text { storms }\end{array}$ & $\begin{array}{c}50-89 \mathrm{~mm} / \mathrm{hr} \text {., heavy } \\
\text { rainfall, hail, strong wind } \\
\text { gust and tornadoes }\end{array}$ \\
\hline Extremely & $\begin{array}{c}\text { above } 90 \mathrm{~mm} / \mathrm{hr} ., \text { heavy } \\
\text { rainfall, hail, strong wind } \\
\text { gust and tornadoes }\end{array}$ \\
\hline
\end{tabular}

However, the territory of regions and districts is relatively large, so it is essential to use a predictive tool to provide more accurate predictive information on the occurrence of convective precipitation and other dangerous phenomena. This predictive tool is the Algorithm of Storm Prediction proposed in the dissertation work of the author of this article.

\subsection{The algorithm of Storm Prediction}

The Algorithm of Storm Prediction was developed as a desktop application to provide predictive information on severe convective storms. This algorithm uses the principles of analysis and evaluation of predictive meteorological elements and parameters from NWP models, including the evaluation of orography effects and the use of a database of approximately 200 historical weather situations $[3,4]$.

The output of the algorithm is a report that contains prediction information:

- precipitation occurrence - municipalities with extended powers (MEP) and its regions,

- time of precipitation occurrence and

- forecast lead time with $6-24 \mathrm{hr}[3,4]$.
Figure 1 demonstrate that predictive algorithm outputs are computed through ten phases. The null phase is focused on converting input data from NWP models and other sources (database of historical situations and relief characteristics, alerts from CHMI and ESTOFEX) to coefficient values in the interval 0-3.

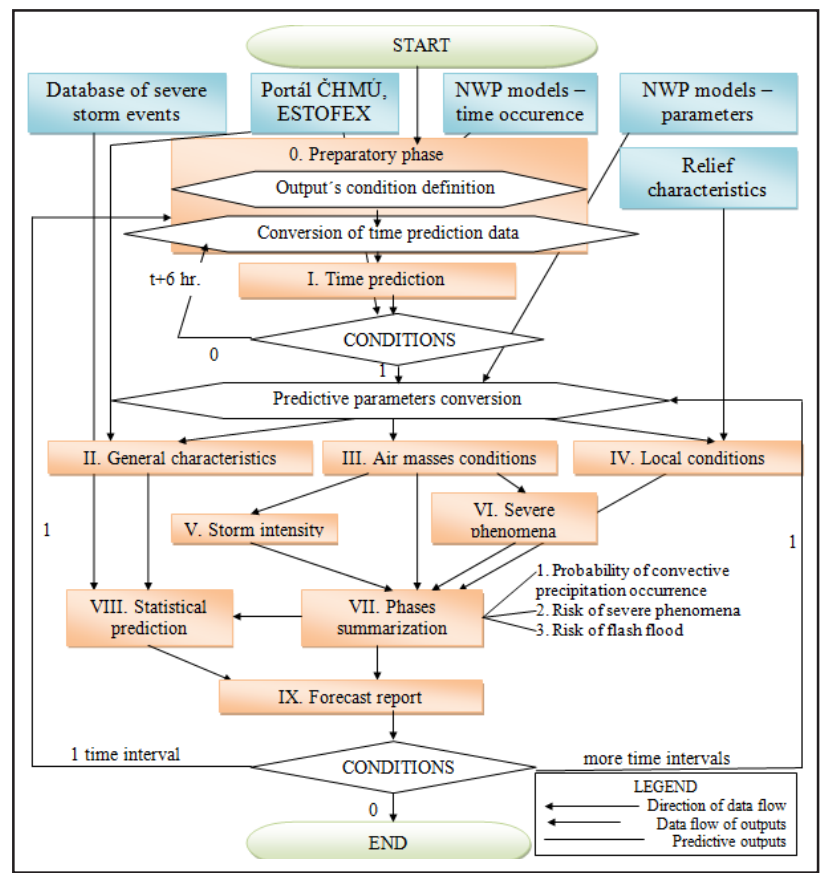

Fig. 1. Flowchart of Algorithm of Storm Prediction [3, 4]

Forecasting outputs are computed for each 3-hour interval separately. In the first phase, 3-hour intervals are determined on the forecast of precipitation from seven NWP models with a horizontal resolution of fewer than $11 \mathrm{~km}$. The second phase summarizes crucial predictive information, in particular about the warnings of the CHMI and ESTOFEX. The third phase predicts conventional properties in the atmosphere. The fourth stage predicts conditions of temperature, humidity and airflow in the boundary layer of the atmosphere including orographic effects to predict the conditions for the initiation of atmospheric convection. This phase forms the core of a precision forecast of the probability of convective precipitation. The fifth phase predicts the storm intensity, which is compared with the warnings of the CHMI and ESTOFEX. The occurrence probability of dangerous phenomena such as torrential rainfall, hail, strong wind gusts and tornadoes are predicted in the sixth phase. The aim of the seventh phase is merging outputs from third to sixth phases, which are accompanied by a statistical prediction of convective precipitation in the eighth phase. The ninth phase summarizes and visualizes these forecast outputs to maps for the MEP and regions:

- general characteristics of the predicted situation (alg.)

- forecast of the probability of convective precipitation occurrence (alg.),

- forecast of storm intensity (alg.),

- forecast of the risk of flash floods (alg.),

- forecast of time probability and precipitation occurrence (NWP models) and 
- forecast of the risk of dangerous phenomena (alg.).

- statistical prediction of the probability of convective precipitation (alg.) [3, 4].

The situation associated with flash floods are analyzed and evaluated by boldly marked prediction outputs.

Predictive outputs are calculated as their probability values which is recalculated to coefficient values in the range from 0 to 3 according to the formula:

$$
P_{h_{i}}=\frac{\sum_{j=1}^{k} v_{j} y_{i j}}{3 \sum n},
$$

where yij are values of the critical matrix Y (values of coefficients, converted predictive parameters from NWP models) and $v j$ is the weight of the $j$-th criterion which is weighted coefficient values of predictive parameters. $\Sigma$ n represents the sum of predictive parameters in a partial or main output $[3,4]$.

2.1.1 Forecast of the probability of the rainfall intensity and its occurrence

This forecast output is calculated from outputs of the fourth and fifth phase (Storm Intensity + Local Conditions) according to formula 1 . Verification of this output is performed with data from the stationary measurement of CHMI network $[3,4]$.

\subsubsection{Forecast of storm intensity}

Storm intensity forecast is calculated from partial outputs of the third phase according to formula 1:

- day or night atmosphere instability,

- comprehensive support for convection mechanisms,

- deep layer shear in levels 0 - $6 \mathrm{~km}$,

- propagation, and motion of storms.

This output is compared with the CHMI alerts for a dangerous Storm phenomenon for its verification [3, 4].

\subsubsection{Forecast of the risk of flash floods}

Risk of flash floods is calculated by combining the critical prediction algorithm outputs (formula 1):

- the degree of soil saturation,

- the number of potential risk precipitations in 1 hour,

- the probability of convective precipitation,

- the storm intensity,

- the propagation and motion of storms,

- the summary of dangerous phenomena [3, 4].

The risk of flash floods is verified by the Czech Hydrometeorological alerts, data from the radar and station measurement of precipitation and flood events reported by the Fire Rescue Service of the Czech Republic.

As can be seen in Table 2, coefficients shown in bold represent high to the very high risk of flash floods, when the determination would be possible to start the implementation of flood prevention measures.

Table 2. Classification of evaluated algorithm outputs $[3,4]$

\begin{tabular}{|c|c|c|c|}
\hline $\begin{array}{c}\text { Coeffici- } \\
\text { ents }\end{array}$ & $\begin{array}{c}\text { Rainfall } \\
\text { probability }\end{array}$ & $\begin{array}{c}\text { Storm intensity } \\
(\mathbf{m m} / \mathbf{h r})\end{array}$ & $\begin{array}{c}\text { Risk of } \\
\text { flash } \\
\text { flood }\end{array}$ \\
\hline 0 & $0-0,24$ & Weak $(0-29)$ & $\begin{array}{c}\text { Very } \\
\text { low }\end{array}$ \\
\hline 1 & $0,25-$ & $\begin{array}{c}\text { Strong }(30- \\
49)\end{array}$ & Low \\
\hline $\mathbf{2}$ & 0,49 & $\begin{array}{c}\text { Very strong } \\
(50-89)\end{array}$ & High \\
\hline $\mathbf{3}$ & 0,74 & $\begin{array}{c}\text { Extrem ely } \\
\text { strong (nad } \\
90)\end{array}$ & $\begin{array}{c}\text { Very } \\
\text { high }\end{array}$ \\
\hline
\end{tabular}

Verification of predicted outputs is performed by the Accuracy fundamental verification criterion using the pivot table according to the equation:

$$
A=\frac{a+d}{a+b+c+d} \times 100(\%),
$$

where $a$ is the number of cases where the phenomenon was predicted and actually occurred; $b$ is the number of cases where the phenomenon was not predicted and actually occurred; $c$ is the number of cases where the phenomenon was predicted and did not actually occur, and $d$ is the number of instances when the phenomenon was not predicted and did not actually occur.

The Accuracy verification criterion is calculated for each three-hour interval separately, both for municipalities with extended powers and their regions according to the equation:

$$
\bar{X}=\frac{1}{n} \sum_{i=1}^{n} x_{i},
$$

where $\sum x_{i}$ is the sum of categories $a, b, c, d$, which is evaluated for each situation separately [3].

\section{Results}

This chapter focuses on results of verification algorithm outputs with the measured radar and station data of CHMI associated with flash floods in the Zlín Region:

- July 24, 2015,

- August 5, 2016,

- July 22, 2017.

\subsection{Flash flood on July 24,2015}

Flood event of July 24, 2015, was characterized by its unexpected emergence and rapid progression. The leading cause of flash floods was cold front above western Slovakia to create favorable conditions in the atmosphere because of its high instability and significant wind shear [3]. 
Table 3 shows that a low risk of flash floods was predicted for the central, western, northern and northeastern territory of the Zlin region. High risk was calculated for MEP Zlín, where actual floods occurred and caused damage to property and infrastructure in the order of tens of millions of crowns.

Table 3. Verification of flood event on July 24, 2015 [3]

\begin{tabular}{|c|c|c|c|c|}
\hline $\begin{array}{c}24.7 .2015 \\
(18-21: 00)\end{array}$ & $\begin{array}{l}\text { Predi- } \\
\text { ction }\end{array}$ & Reality & $\begin{array}{l}\text { Predi- } \\
\text { ction + } \\
\text { reality }\end{array}$ & $\begin{array}{c}\text { Predi- } \\
\text { ction }\end{array}$ \\
\hline $\begin{array}{l}\text { MEP of the } \\
\text { Zlín region, } \\
\text { reported } \\
\text { flash flood } \\
\text { event }\end{array}$ & $\begin{array}{c}\text { Rainfall } \\
\text { intesity } \\
(\mathrm{mm} / \\
3 \mathrm{hr} .)\end{array}$ & $\begin{array}{l}\text { Rainfall in } \\
\text { mm (the } \\
\text { name of } \\
\text { station) }\end{array}$ & $\begin{array}{l}\text { Rain- } \\
\text { fall } \\
\text { inten- } \\
\text { sity } \\
(\mathrm{mm} / \\
\mathrm{hr} .)\end{array}$ & $\begin{array}{l}\text { Risk of } \\
\text { flash } \\
\text { flood }\end{array}$ \\
\hline Uh.Hradiště & 0 & $\begin{array}{c}7 \text { - Staré } \\
\text { Hutě }\end{array}$ & $0-29$ & 0 \\
\hline Otrokovice & $3-9$ & 0 & $0-29$ & low \\
\hline Kroměříǐž & $3-9$ & $\begin{array}{c}6- \\
\text { Kroměřížz }\end{array}$ & $0-29$ & low \\
\hline Holešov & $3-9$ & 6 - Holešov & $0-29$ & low \\
\hline Zlín & $10-29$ & 23 - Zlín & $0-29$ & high \\
\hline Bystřice & $3-9$ & 4 - Bystřice & $0-29$ & low \\
\hline $\begin{array}{l}\text { Valašské } \\
\text { Meziříčí }\end{array}$ & 0 & 0 & $0-29$ & low \\
\hline Rožnov & $3-9$ & 0 & $0-29$ & low \\
\hline Vsetín & $3-9$ & $\begin{array}{c}12- \\
\text { (Maruška) }\end{array}$ & $0-29$ & low \\
\hline Vizovice & $3-9$ & 4 Vizovice & $0-29$ & low \\
\hline $\begin{array}{l}\text { Valašské } \\
\text { Klobouky }\end{array}$ & $3-9$ & 0 & $0-29$ & 0 \\
\hline Luhačovice & $3-9$ & 0 & $0-29$ & 0 \\
\hline Uh. Brod & 0 & 0 & $0-29$ & 0 \\
\hline
\end{tabular}

Table 3 provide a more detailed verification where the most intense rainfall was measured in the Zlin region at the Zlin station $(23 \mathrm{~mm})$, where local floods were reported by the authorities of the region's crisis management and Fire Rescue System of Czech Republic.

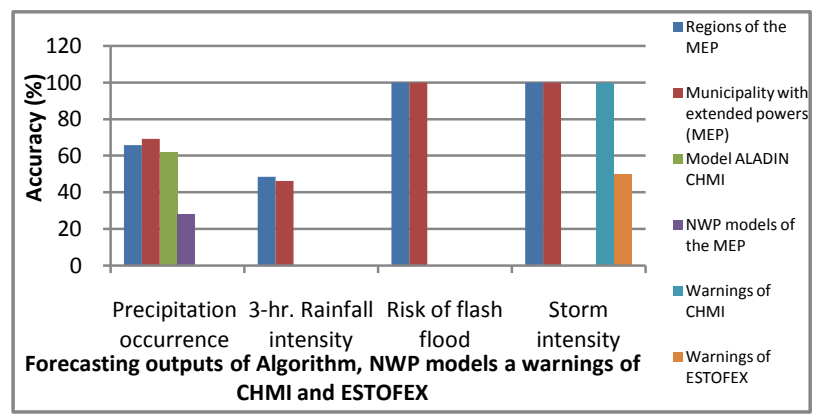

Graph 1. The accuracy of predictive outputs on July 24, 2015 [3]

Graph 1 provide the results of verification by Accuracy for flood event July 24, 2015. The risk of flash floods reached the highest value in comparison with the Czech Hydrometeorological Institute, which did not issue the alert, very favorable assumption of correct configuration algorithm for prediction of flash floods.

\subsection{Flash flood on August 5, 2016}

This flood event occurred at a time when it rained in the whole territory of the Zlín Region in previous days. The primary cause of flash floods was the cold front [3].

Table 4. Verification of flood event on August 5, 2016 [3]

\begin{tabular}{|c|c|c|c|c|}
\hline $\begin{array}{c}5.8 .2016(21- \\
24: 00)\end{array}$ & $\begin{array}{l}\text { Predi- } \\
\text { ction }\end{array}$ & Reality & $\begin{array}{l}\text { Predi- } \\
\text { ction + } \\
\text { reality }\end{array}$ & $\begin{array}{l}\text { Predi- } \\
\text { ction }\end{array}$ \\
\hline $\begin{array}{l}\text { MEP of the } \\
\text { Zlín region, } \\
\text { reported } \\
\text { flash flood } \\
\text { event }\end{array}$ & $\begin{array}{c}\text { Rainfall } \\
\text { intesity } \\
(\mathrm{mm} / \\
3 \mathrm{hr} .)\end{array}$ & $\begin{array}{l}\text { Rainfall in } \\
\text { mm (the } \\
\text { name of } \\
\text { station) }\end{array}$ & $\begin{array}{l}\text { Rain- } \\
\text { fall } \\
\text { inten- } \\
\text { sity } \\
\text { (mm/ } \\
\text { hr.) }\end{array}$ & $\begin{array}{c}\text { Risk of } \\
\text { flash } \\
\text { flood }\end{array}$ \\
\hline Uh.Hradiště & $10-29$ & $\begin{array}{c}11 \text { - Staré } \\
\text { Hutě }\end{array}$ & $30-49$ & 0 \\
\hline Otrokovice & $3-9$ & 8 - Košíky & $0-29$ & 0 \\
\hline Kroměříž & $3-9$ & $\begin{array}{c}8 \text { - } \\
\text { Kroměříž }\end{array}$ & $0-29$ & 0 \\
\hline Holešov & $3-9$ & 9 - Holešov & $0-29$ & 0 \\
\hline $\begin{array}{c}\text { Zlín } \\
\text { (povodeň) }\end{array}$ & $3-9$ & $\begin{array}{c}6 \text { - Zlín- } \\
\text { Štípa }\end{array}$ & $0-29$ & low \\
\hline Bystřice & $10-29$ & $\begin{array}{c}9- \\
\text { Bystřice }\end{array}$ & $30-49$ & low \\
\hline $\begin{array}{l}\text { Valašské } \\
\text { Meziříčí }\end{array}$ & $3-9$ & $\begin{array}{c}7 \text {-Valašské } \\
\text { Meziříćí }\end{array}$ & $30-49$ & low \\
\hline Rožnov & $3-9$ & $\begin{array}{l}15 \text { - Horní } \\
\text { Bečva }\end{array}$ & $30-49$ & low \\
\hline Vsetín & $10-29$ & $\begin{array}{l}24 \text { - Val. } \\
\text { Senice }\end{array}$ & $30-49$ & low \\
\hline Vizovice & $0-3$ & $\begin{array}{c}9- \\
\text { Vizovice }\end{array}$ & $30-49$ & low \\
\hline $\begin{array}{l}\text { Valašské } \\
\text { Klobouky }\end{array}$ & $10-29$ & $\begin{array}{c}21- \\
\text { Brumov- } \\
\text { Bylnice }\end{array}$ & $30-49$ & high \\
\hline Luhačovice & $10-29$ & $\begin{array}{l}14 \text { - Luha- } \\
\text { čovice }\end{array}$ & $30-49$ & low \\
\hline Uh. Brod & $10-29$ & 14 - Strání & $30-49$ & low \\
\hline
\end{tabular}

As can be seen in Table 4, high risk was predicted for the Vsetín and Valašské Klobouky regions, where a local flash flood occurred on the Brumovka river between 22 and 23 o'clock. This flood has caused enormous damage mainly to the infrastructure and property of the population. The intensity of strong storms was predicted for nearly two-thirds of the region, but only in the Valašské Klobouky region, there was a flash flood where 
the second highest rainfall was measured at the BrumovBylnice station $(21 \mathrm{~mm})$.

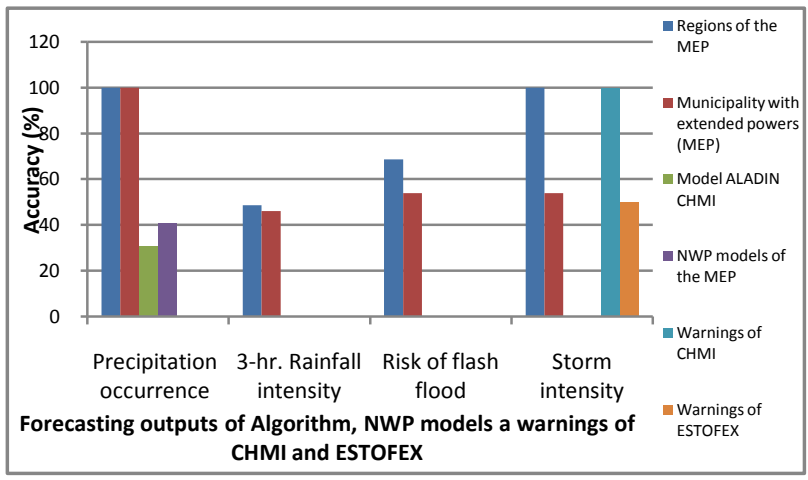

Graph 2. The accuracy of predictive outputs on August 5, 2016 [3]

Graph 2 shows the very high success rate of convective rainfall occurring throughout the Zlín Region. On the contrary, lower values were at the storm intensity. Predicting the risk of flash floods correspond with reality, which was reported flash flood in the MEP of Valašské Klobouky. On the other hand, the Czech Hydrometeorological Institute again did not issue a warning, even though the presence of some factors (for example extreme soil saturation) recorded a probable flood event in the eastern of the Czech Republic.

\subsection{Flash flood on July 22,2017}

The last evaluated flood event was the situation on July 22, 2017, when there were very intense convective precipitation between villages of Horní Lhota and Luhačovice in a concise time (approximately 60-90 minutes). The leading cause of flash floods was occluded front, where there was rainfall intensity of $30 \mathrm{~mm} / \mathrm{hr}$. in combination with strong wind shear. Just wind shear caused the stationary movement of the severe storm, which led to the formation of the flash flood [3].

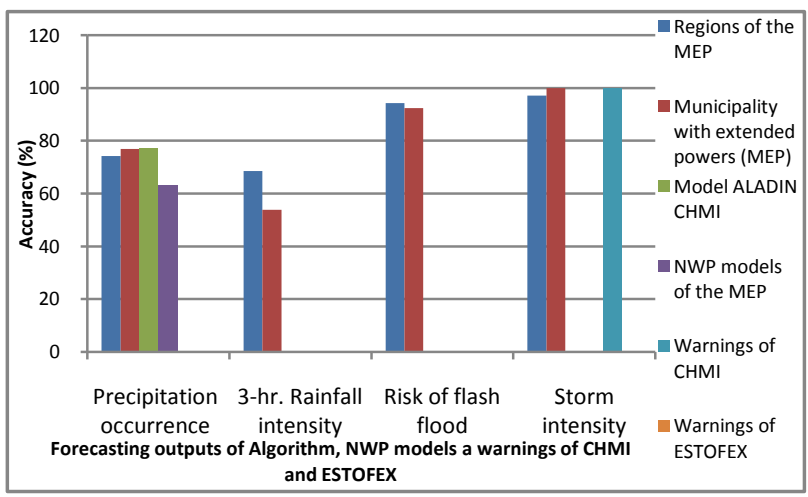

Graph 3. Accuracy of predictive outputs on July 22, 2017 [3]

As can be seen in the Graph 3, algorithm and NWP models have the high predictability of convective precipitation. The highest success rate was achieved in predicting the risk of flash floods and storm intensity (the algorithm and warnings of the CHMI). The forecast of the flash flood risk corresponded to the fact that a flood in the Luhačovice MEP was reported. Czech Hydrometeorological warnings were issued for the entire territory of the Zlin Region and despite that flash flood occurred in only one district.

Table 5. The accuracy of predictive outputs on July 22, 2017 [3]

\begin{tabular}{|c|c|c|c|c|}
\hline $\begin{array}{c}\text { 22.7.2017 } \\
\text { (15-18:00) }\end{array}$ & $\begin{array}{c}\text { Predi- } \\
\text { ction }\end{array}$ & Reality & $\begin{array}{c}\text { Predi- } \\
\text { ction }+ \\
\text { reality }\end{array}$ & $\begin{array}{c}\text { Predi- } \\
\text { ction }\end{array}$ \\
\hline $\begin{array}{c}\text { MEP of the } \\
\text { Zlín region, } \\
\text { reported } \\
\text { flash event }\end{array}$ & $\begin{array}{c}\text { Rainfall } \\
\text { intesity } \\
\text { (mm/ }\end{array}$ & $\begin{array}{c}\text { Rainfall in } \\
\text { mm (the } \\
\text { name of } \\
\text { station) }\end{array}$ & $\begin{array}{c}\text { Rain-fall } \\
\text { inten-sity } \\
\text { (mm/ hr.) }\end{array}$ & $\begin{array}{c}\text { Risk of } \\
\text { flash } \\
\text { flood }\end{array}$ \\
\hline Uh.Hradiště & 0 & $3-$ Hluk & $0-29$ & 0 \\
\hline Otrokovice & 0 & 0 & $0-29$ & 0 \\
\hline Kroměříž & 0 & 0 & $0-29$ & 0 \\
\hline Holešov & 0 & 0 & $0-29$ & 0 \\
\hline $\begin{array}{c}\text { Zlín } \\
\text { (povodeň) }\end{array}$ & $10-29$ & 0 & $0-29$ & $10 \mathrm{~W}$ \\
\hline Bystřice & 0 & 0 & $0-29$ & 0 \\
\hline $\begin{array}{c}\text { Valašské } \\
\text { Meziříćí }\end{array}$ & 0 & 0 & $0-29$ & 0 \\
\hline Rožnov & 0 & 0 & $0-29$ & 0 \\
\hline Vsetín & $3-9$ & $3-$ Val. \\
\hline Polanka & $0-29$ & 0 \\
\hline $\begin{array}{c}\text { Valašské } \\
\text { Klobouky }\end{array}$ & $3-9$ & 0 & $0-29$ & 0 \\
\hline Luhačovice & $30-49$ & $36-$ Horni \\
Lhota & $30-49$ & $h i g h$ \\
\hline Uh. Brod & 0 & 0 & $0-29$ & 0 \\
\hline
\end{tabular}

Table 5 show that this situation was characterized by the presence of strong local precipitations measured at Horní Lhota station (36 mm / hour), which had a significant influence on the formation of the flash flood. The forecast corresponded to the actual state. High risk was predicted only for the Luhačovice region, where 58 $\mathrm{mm} / 2$ hours precipitation was measured. The flash flood affected the isolated area and damaged the transport infrastructure.

\section{Conclusion}

This article aimed to provide information on the new forecasting tool (Algorithm of Storm Prediction) regarding its evaluation success rate in three flash flood events that hit the Zlín Region in years of 2015-2017.

Verified predicted outputs of the algorithm were the probability of the precipitation occurrence, storm 
intensity, and the flash flood risk, which was calculated to a high degree for all flood events. It corresponded to the fact that there were floods occurred in the regions.

On the contrary, the CHMI issued warnings on dangerous phenomena of severe strong storms in only one case (July 22, 2017), which is a severe problem regarding inaccurate information on early warning of flash floods.

The limitation of this study is the insufficient number of evaluated flood events. Future research will focus on testing and verification of dozens of flood events not only for the Zlin Region but the whole of the Czech Republic.

This work was supported by the project No. CEBIA-Tech LO1303, A2.4 - ICT for support of crisis management.

\section{References}

1. D. Procházková, Methodology to estimate the cost of recovering assets in areas affected by natural or other disasters (2007)

2. I. Obrusník, Meteorological bulletin, 59, 8 (2006)

3. D. Šaur, Information support for crisis management of the region in terms of assessment of flood events, 172 (2017)

4. D. Šaur, Algorithm of Storm Prediction: Technical specification (2018)

5. IPCC AR4 WG1. Available at: https://www.ipcc.ch/publications_and_data/ ar4/wg1/en/tssts-5-3.html (1997 - 2018)

6. J. Lu, G. A. Vecchi, T. Reichler, J. Geophysical Research Letters, 34, 6 (2007)

7. Phys.org, Available at: http://phys.org/news/2015-12-sea-icearctic-precipitation-complicates.html (2015)

8. K.S. Singh, K. Prasad Bhasakaran, E. Glesson, et al., J. of Atmospheric and Solar-Terrestrial Physics, 165-166, 14 (2017)

9. K. Lagouvardos, V. Kotroni, E. Defer and O. Bousquet, J. Atmospheric research, 134, 11 (2013)

10. G. Wang, W. Wai-Kin, Y. Hong, L. Liu and J. Dong. J., Atmospheric Research, 154, 10 (2015)

11. H. Wang, Y. Liu, W. Y. Y. Cheng, et al., J. of Geophysical Research: Atmospheres, 122, 22 (2017)

12. Y. Lepoittevin, I Herlin, International Geoscience and Remote Sensing Symposium (IGARSS), 14 (2015)

13. K. Liechti, M. Zappa, F. Fundel, U. Germann, J. Hydrological Processes, 27, 13 (2013)

14. V. Lakshmanan, J. Crockett, K. Sperow, M. Ba, L. Xin, J. Weather and Forecasting, 27, 12 (2012)

15. L. Panziera, U. Germann, M. Gabella and P. V. Mandpaka, J. of the Royal Meteorological Society, 137, 18 (2011)
16. L. Nisi, P. Ambroseti a L. Clementi, J. of the Royal Meteorological Society, 682, 16 (2014)

17. Czech Hydrometeorological Institute, Available at: http://portal.chmi.cz/files/portal/docs/meteo /om/sivs/bourky.html (1997 - 2018) 